\title{
Cave Symphyla from Switzerland
}

\author{
by
}

\section{UIf SCHELLER}

Lundsberg, Sweden.

With one figure

In two papers Dr. Hermann Gisin reported some Symphyla from Switzerland about ten years ago (1949 and 1951). During his soil fauna investigations he frequently met with three of them, Symphylella vulgaris (Hansen), Symphylellopsis subnuda (Hansen) and Scutigerella immaculata (Newport). These species were much more abundant than the remaining ones, viz. Symphylella isabellae (Grassi), Scolopendrella notacantha Gervais, Geophilella pyrenaica Ribaut and Hanseniella nivea (Scopoli). The statement of the occurrence of the Scutigerella species mentioned in the first paper (1949) was then given a critical re-examination by the same author and in the paper from 1951, after that he had studied the Scutigerella specimens more in detail and penetrated Michelbacier's synopsis of the genus, he referred them to nodicercus Michelbacher.

To these seven Swiss species the present author can now add two more: Scutigerella immaculata (Newport) emend. Michelbacher and a new species of the genus Symphylella which is described in the following. The material which has yielded this result has been collected by Dr. V. Aellen, Ch. Roth and P. Strinati during their study of the cave fauna of Switzerland and I am indepted to them for their permission to examine it.

\section{Fam. SCOLOPENDRELLIDAE}

\section{Symphylella major, n. sp.}

Material. - Canton de Vaud, commune de L'Abbaye, the cave La Chaudière d'Enfer, $1070 \mathrm{~m}$ a. s. (Aellen and Strinati 1956, p. 185, VD 4), 17.VIII.1960, 1 ad. 
The type has been deposited in the collections of the Natural History Museum, Geneva.

This new symphylid was collected in a very moist layer of clay deep within the cave. The humidity of this cave is very high. There is a permanent subterranean lake where a typical cave dweller, the amphipod Niphargus virei Chevr., appears. The terrestrial troglobic fauna is characterized by the two collembolans Isotomurus alticola (Carl) and Pseudosinella vandeli Den., and the beetle Royerella villardi sermeti Jeann.

Length. $-5.25 \mathrm{~mm}$.

Head. - 1.2 times longer than broad with broadest part a little behind the middle on a level with the flatly rounded points of articulation of mandibles. The cutting edge of the latter with two rudimentary teeth in its middle portion. Central rod well marked but rather thin with middle interruption and lateral branches lacking and anterior branches feebly developed. A little behind the middle of the rod there is a small swelling with diminutive rudiments of median lateral branches placed at nearly right angles to the rod. The latter ends backwards with an oval body at the anterior angle of the triangular area of the hind part of the head. Dorsal surface of head covered with straight medium size setae. On the front margin of the labrum there are 4 protruding setae, the lateral ones longest. Diameter of postantennal organs reaching somewhat more than 0.6 of the greatest diameter of 3rd antennal segment.

Antennae. - Antennae complete; each of them with 24 segments. The short incomplete basal segment distinct but lacks setae. First segment well developed with 6 setae in the primary whorl evenly distributed on dorsal, inner lateral and ventral sides. Three of them, all on the inner and inner ventral side, strongly protruding and longer than the others; they are fixed to low protuberances, the others not. On proximal part of inner dorsal side there is a single small, thin seta protruding from a low protuberance. This segment somewhat longer and thinner than second segment. The latter with primary whorl complete, comprising 10 setae inserted on all sides. The inner ones longer than the others and of the same type as corresponding setae of preceding segment. An inner dorsal seta longest being nearly 0.5 of greatest 


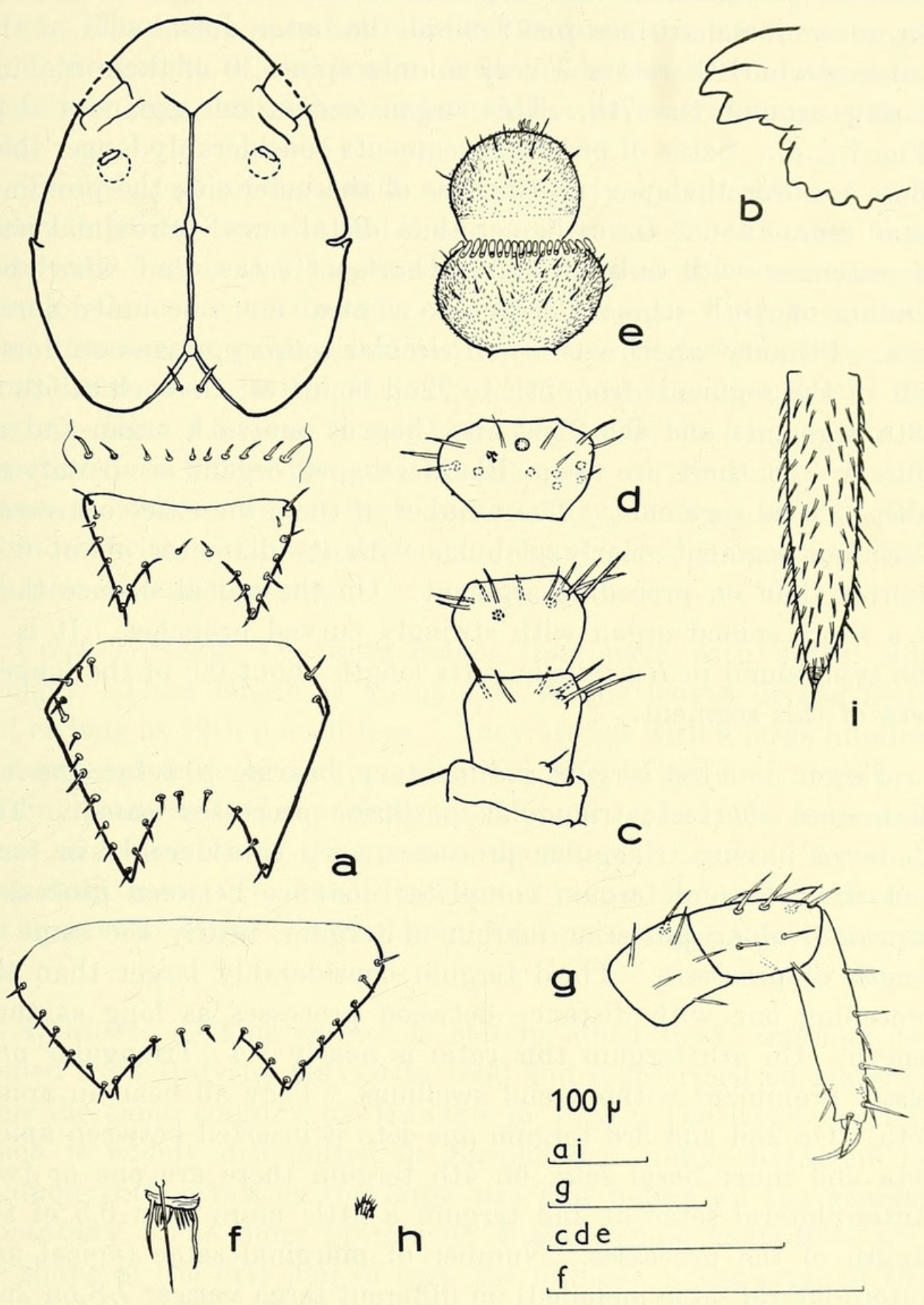

FIG. 1

Symphylella major, n. sp.

a) head and first 4 terga (only marginal setae drawn; right margin of 3rd tergum not suitable for study). b) mandible. c.e) left antenna. from above: $c$, basal part; $d, 10$ th segment; $e$, last two segments. j) first leg. g) 12 th leg. $h)$ stylus of $121 \mathrm{~h} \mathrm{Jeg.} \mathrm{i)} \mathrm{right} \mathrm{cercus,} \mathrm{from} \mathrm{above.}$ 
diameter of segment. This segment 1.4 times broader than long. On outer dorsal surface just behind the outer dorsal seta of the primary whorl there are 7 very minute spines, 6 of them making a ring arcund the 7th. This organ occurs on segments 2-12 (Fig. $1 c, d$ ). Setae of proximal segments considerably longer than those towards the apex: in the case of the inner side the proximal setae more than 3 times longer than distal ones. Proximal part of antennae with only primary whorls of setae, 2nd whorl beginning on 10th segment with two ventral and one inner dorsal seta. Primary whorl with small circular sensory organs on dorsal side of the segments from 5 th to 22 nd inclusive. On each of 5 th to 18th segments and the 22nd one there is one such organ and on 19th to 21 st there are two. Bladdershaped organs occur only on 20th to 23rd segments. The number of them increases outwards. Terminal segment nearly globular with its diameter about 0.25 shorter than on preceding segment. On the apical surface there is a short spined organ with strongly curved branches. It is of the type found in Ribautiella. Its length about 0.5 of the longest seta of this segment.

Terga. - First tergum rudimentary, bearing 10 setae, the median ones shortest; triangular posterior processes absent. The 13 terga having triangular processes vary considerably in form and size. Second tergum complete; distance between processes, measured along posterior margin of tergum, nearly the same as length of processes. Third tergum considerably larger than the preceding one with distance between processes as long as their length. On 4th tergum this ratio is nearly 1.4 Triangular processes prominent without end swellings. They all bear an apical seta. On 2nd and 3rd tergum one seta is inserted between apical seta and inner basal seta, on 4th tergum there are one or two. Antero-lateral setae of 2 nd tergum a little more than 0.5 of the length of the processes. Number of marginal setae (apical and antero-lateral setae included) on different terga varies: 7-8 on 2nd, 10 on 3rd, 6 or 7 on 4th. Surface of terga provided with straight setae of medium size. Form and chaetotaxy of head and first 4 terga is seen in fig. $1 a$.

Legs. - All pairs well developed except the first one which is reduced to two small strongly flattened knobs with several hairs 
somewhat longer than the knob. They are also set with two real setae. They are somewhat curved, the longest one 5 times longer than the height of the knob. Just inside the base of the knob there is a long straight seta nearly twice as long as longest knob seta.

Twelfth pair of legs with tarsus nearly eylindrical and only feebly tapering towards distal end. It is 4.3 times longer than wide with 7 setae in all inserted in two rows on the outer surface. Four of them are outstanding, 3 are depressed. Length of these setae increases towards distal end of tarsus, longest seta being the most distal one. Its length is 0.9 of the greatest diameter of the tarsus. Tibia 1.6 times longer than wide with the longest seta of upper surface 0.6 of the greatest diameter of the joint. Femur about as wide as long. Styli rudimentary, as long as wide and provided with a fine pubescence. Coxal sacs at bases of 3rd9 th pair of legs inclusive.

Cerci. - Cerci 4.6 times longer than wide with dorsal side straight. Their length is about $1 / 17$ of the length of the body and as long as 12th pair of legs. They are set with a large number of depressed setae of medium size and 8-10 longer and more protruding setae located especially on the outer side. The longest of these setae not 0.5 of the greatest diameter of cercus. Terminal area short being 0.3 of the diameter of cercus and provided with 8-9 transverse striae. Apical seta 1.2 times longer than terminal area.

Affinities. - This species is closely allied to $S$. isabellae described from Italy by Grassi in 1886 and redescribed on material from the same country by Hansen in 1903. The latter species, which is widely distributed in Europe has many characters in common with major as the large size and before all the general chaetotaxy. The more prominent distinguishing characters are: the shape of the first pair of legs, the number of the setae of the tarsus of the 12th pair of legs, the shape of the styli, the structure of the cutting edge of the mandibles and the number of tergal setae.

A peculiarity of $S$. major is the occurrence on the antennal segments 2-12 of a small structure which must be considered as a very beginning of or a rudiment of the spined organs in fam. Scutigerellidae. 


\section{Symphylella vulgaris (Hansen)}

Material. - Canton de Berne, commune de Sonvilier, the cave Echelette, 1220 m. a. s. (Aellen and Strinati 1956, p. 188, BE 7), 30.XII.1957, 2 ad., 1 juv. with 8 pairs of legs.

\section{Fam. SCUTIGERELLIDAE}

Scutigerella immaculata (Newport) emend. Michelbacher

Material. - Canton de Genève, commune de Vernier, the cave in Bois des Frères, 390 m. a. s. (Aellen and Strinati 1956, p. 185, GE 1), 11.XII.1956, 1 ad. - Canton de Berne, commune de Sonvilier, the cave Echelette, $1220 \mathrm{~m}$ a. s. (BE 7), 30.XII.1957, 1 ad.

\section{ZUSAMMENFASSUNG}

Es werden drei Arten von Symphylen aus schweizerischen Höhlen gemeldet, wovon zwei neu für die Schweiz und eine neu für die Wissenschaft sind.

\section{RÉSU MÉ}

L'auteur signale la capture de trois espèces de Symphyles dans des grottes de la Suisse, dont deux sont nouvelles pour la faune de ce pays, et une espèce est nouvelle pour la science.

\section{REFERENCES}

Aellen, V. and P. Strinati. 1956. Matériaux pour une faune cavernicole de la Suisse. Rev. suisse Zool. 63: 183-202.

Gisin, H. 1949. Symphyles de la Suisse. Arch. Sci. 2: 182-186.

- 1951. Sur les espèces européennes de Scutigerella (Myriapodes Symphyles). Vie et Milieu 2: 459-460.

Grassi, B. 1886. Morfologia delle Scolopendrelle. Mem. R. Accad. Sci. Torino (2) 37: 593-624.

Hansen, H. J. 1903. The Genera and Species of the Order Symphyla. Quart. J. micr. Sci. 47: 1-101, Pl. 1-7.

Michelbacher, A. E. 1942. A synopsis of the genus Scutigerella. Ann. ent. Soc. Amer. 35: 267-288. 


\section{$2 \mathrm{BHL}$ Biodiversity Heritage Library}

Scheller, Ulf. 1961. "Cave Symphyla from Switzerland." Revue suisse de zoologie 68, 419-424. https://doi.org/10.5962/bhl.part.75091.

View This Item Online: https://www.biodiversitylibrary.org/item/126525

DOI: https://doi.org/10.5962/bhl.part.75091

Permalink: https://www.biodiversitylibrary.org/partpdf/75091

\section{Holding Institution}

Smithsonian Libraries

\section{Sponsored by}

Biodiversity Heritage Library

\section{Copyright \& Reuse}

Copyright Status: In Copyright. Digitized with the permission of the rights holder

Rights Holder: Muséum d'histoire naturelle - Ville de Genève License: http://creativecommons.org/licenses/by-nc-sa/3.0/ Rights: https://www.biodiversitylibrary.org/permissions/

This document was created from content at the Biodiversity Heritage Library, the world's largest open access digital library for biodiversity literature and archives. Visit BHL at https://www.biodiversitylibrary.org. 